\title{
Article \\ The Effect of Microbial Fertilizer on the Growth, Rhizospheric Environment and Medicinal Quality of Fritillaria taipaiensis
}

\author{
Nong Zhou ${ }^{1,2, *}$, Maojun Mu ${ }^{1,2}$, Min Yang ${ }^{2}$, You Zhou ${ }^{1, *(\mathbb{D})}$ and Mingguo Ma ${ }^{3, * \mathbb{C}}$ \\ 1 Chongqing Engineering Laboratory of Green Planting and Deep Processing of Famous-Region Drug in the \\ Three Gorges Reservoir Region, College of Biology and Food Engineering, Chongqing Three Gorges \\ University, Chongqing 404120, China; 18780118293@163.com \\ 2 College of Chemistry and Pharmaceutical Sciences, Dali University, Dali 671000, China; \\ dldxyangmin@163.com \\ 3 Engineering Research Center of Forestry Biomass Materials and Bioenergy, Beijing Key Laboratory of \\ Lignocellulosic Chemistry, College of Materials Science and Technology, Beijing Forestry University, \\ Beijing 100083, China \\ * Correspondence: 20120038@sanxiau.edu.cn (N.Z.); 20170013@sanxiau.edu.cn (Y.Z.); \\ mg_ma@bjfu.edu.cn (M.M.); Tel.: +86-23-5810-2130 (N.Z.); +86-23-5810-2130 (Y.Z.); +86-10-6233-7250 (M.M.)
}

Citation: Zhou, N.; Mu, M.; Yang, M.; Zhou, Y.; Ma, M. The Effect of Microbial Fertilizer on the Growth, Rhizospheric Environment and Medicinal Quality of Fritillaria taipaiensis. Horticulturae 2021, 7, 500 . https://doi.org/10.3390/

horticulturae7110500

Academic Editor: Harald Scherm

Received: 7 October 2021

Accepted: 11 November 2021

Published: 15 November 2021

Publisher's Note: MDPI stays neutral with regard to jurisdictional claims in published maps and institutional affiliations.

Copyright: (c) 2021 by the authors. Licensee MDPI, Basel, Switzerland. This article is an open access article distributed under the terms and conditions of the Creative Commons Attribution (CC BY) license (https:// creativecommons.org/licenses/by/ $4.0 /)$
Abstract: Fritillaria taipaiensis is a valuable traditional Chinese medicinal plant affected by germplasm degradation during cultivation. To find a suitable solution for this problem, F. taipaiensis was inoculated with exogenous arbuscular mycorrhiza (AM) fungi, potassium-solubilizing bacteria, and phosphorus-solubilizing bacteria in pot experiments. The effects of inoculation on the AM colonization, photosynthetic pigment, and superoxide dismutase contents, rhizospheric enzyme activities, alkaloid, and nucleotide content of F. taipaiensis were studied. The results showed that the inoculation increased mycorrhizal infection intensity of F. taipaiensis. Compared to the control group, the photosynthetic pigment contents in the leaf of the inoculation groups were increased; the content of soluble protein, the activities of the superoxide dismutase, catalase, and peroxidase in leaves were all significantly increased, and the content of malondialdehyde was decreased. The microbial inoculum also increased the content of active ingredients in F. taipaiensis bulbs and increased the enzyme activities, total microorganism number, bacteria/fungi, and actinomycetes/fungi ratios in the rhizosphere. To sum up, microbial fertilizer can significantly improve the rhizospheric environment and medicinal quality of $F$. taipaiensis. This research provides a theoretical basis and experimental evidence for the sustainable development of an F. taipaiensis industry.

Keywords: Fritillaria taipaiensis; biological fertilizer; abuscular mycorrhiza fungi; potassium solubilizing bacteria; phosphorus solubilizing bacteria; microbial fertilizer

\section{Introduction}

Fritillaria taipaiensis is a perennial herb in the Liliaceae. Its bulbs contain multiple alkaloids, which can cool down body temperature, relieve cough and asthma, and resolve phlegm [1]. The geographical distribution, morphological characteristics, active ingredients, pharmacological effects, and clinical efficacy of F. taipaiensis are similar to those of Fritillaria cirrhosa (Chuanbeimu) [1-3], also known as "antitussive medicine". Therefore, F. taipaiensis has been categorized as a medical material provenance of Chuanbeimu in the 2015 edition of Chinese Pharmacopoeia [4]. Due to the increasing market demand, wild resources of F. taipaiensis are continuously declining, as the herb has been associated with a long growth cycle and over-excavation. Recently, wild F. taipaiensis has been listed as China's third-level national conservation plant $[5,6]$. Thus, active introduction and domesticating of F. taipaiensis to expand its cultivation areas are of great importance for solving the imbalance between the supply and demand of F. taipaiensis [7,8].

At present, numerous cultivation bases of $F$. taipaiensis have been formed at Chongqing, Shaanxi, and Yunnan in China, accelerating the development of F. taipaiensis production 
and increasing the share of $F$. taipaiensis on the market [6]. However, studies have suggested that the alkaloid content and yield of $F$. taipaiensis could not increase during the artificial cultivation process. For example, 3-year-old F. taipaiensis seedlings showed a lower quality in the content of active constituents compared to 1- and 2-year-old F. taipaiensis seedlings $[9,10]$. Moreover, continuous cropping $F$. taipaiensis may be challenging. After 3-4 years of continuous planting, reduced growth potential and disease accumulation may appear, and because of the long term artificial disturbance during the cultivation, the contents of nutrients in the cultivated soil such as available $\mathrm{N}$, available $\mathrm{P}$, available $\mathrm{K}$, and organic matter may significantly decrease due to plant absorption and leaching, thus affecting yield and quality [11].

The failures associated with the soil used for cultivation and the change of rhizospheric microflora are major factors that can induce continuous cropping obstacles [12,13]. Microbial fertilizer has been widely used in the artificial cultivation of precious Chinese medicinal materials, which not only improves the density and structure of microbial population in rhizospheric soil, but also promotes the safety, quality, and yield of Chinese medicinal materials $[9,14]$. Dong et al. [9] improved the microorganism community structure and soil enzyme activity in the rhizosperic soil of F. taipaiensis by using Trichoderma spp. and organic fertilizers under field conditions, promoting the growth and development of 2-year-old F. taipaiensis and effectively increasing the accumulation of alkaloids in its bulbs. Nevertheless, improving the quality of $F$. taipaiensis by microbial cultivation has rarely been reported; there are still many problems to be explored in this field.

Arbuscular mycorrhiza (AM) fungi, beneficial microorganisms extensively distributed in soil, can form a symbiotic relationship with the roots of most higher plants [15]. Researchers found that the external hyphae of AM fungi could extend deeper and farther into the soil to enlarge the absorption range of plant roots, which is helpful for the host plants to absorb nutrients and water [16]. In forest ecosystems, 34-90\% of P that the host plant absorbed could be provided by AM fungi [17]. The AM fungi could also absorb $\mathrm{NH}^{+}{ }^{+}$[18], $\mathrm{NO}^{-}$and small-molecule organic nitrogen [19] directly from the rhizospheric soil and pass them along to the host plant. Meanwhile, AM fungi can increase the $\mathrm{K}$ content in soil and plant rhizomes [20]. In addition, previous studies showed that AM fungi could regulate the metabolic activities in plants [21], promote their growth and development [22], enhance their stress [23] and disease resistance [24], increase their active ingredients content [25-27], and improve their yield and quality [28,29]. However, the effect of AM fungi on F. taipaiensis quality under artificial cultivation conditions has not yet been reported.

Bacillus spp. is a spore-forming bacterium that mainly lives in soil. Thus, many species of this genus are associated with plants as are rhizospheric bacteria and endophytic bacteria [30]. The fundamental function of active compounds from some Bacillus species is the inhibition of plant pathogens, and many species such as B. subtilis, B. amyloliquefaciens, B. licheniformis, B. pasteurii, B. cereus, B. pumilus, and B. mycoides has been reported to be elicitors of induced systemic resistance [31]. Other species of this genus can produce enzymes that dissolve nutrient elements fixed in soil that could be used by plants, such as B. mucilaginosus, which was reported as a potassium solubilizing bacterium [32-34], and B. megaterium, reported as a phosphate and zinc solubilizing bacterium $[35,36]$. The compound application of phosphate solubilizing bacteria, potassium solubilizing bacteria, and AM fungi can efficiently promote plant growth, and the effect of the compound application was much more significant than the single application [37].

Herein, we examined the effects of inoculating exogenous AM fungi on root mycorrhizal colonization, photosynthetic pigment, osmoregulation substance, and active ingredient content, superoxide dismutase and rhizospheric soil enzyme activities, and rhizospheric microbial community structure of $F$. taipaiensis using a pot culture experiment of 3-year-old F. taipaiensis seedlings in simulated field production. In order to further verify the effect of the beneficial microorganisms on the growth of $F$. taipaiensis, we also inoculated potassium solubilizing bacteria and phosphorus solubilizing bacteria in the rhizosphere of F. taipaiensis. The aim of this research was to provide a theoretical basis and experimental 
evidence for the improved quality of $F$. taipaiensis by using beneficial microorganisms in rhizospheric soil.

\section{Materials and Methods}

\subsection{Microbial Inoculum}

The two AM fungi species applied in this study were from the Glomeromycetes (according to the taxonomic system published on the Arthur Schüßler: http:/ / www.amfphylogeny.com/, 12 November 2021), which is a main group of arbuscular mycorrhizal fungi: Claroideoglomus claroideum from the Claroideoglomeraceae family and Racocetra coreoidea from the Gigasporaceae family, both of them widely used in promoting the growth of plants [38]. The AM fungi were purchased from the International Culture Collection of (Vesicular) Arbuscular Mycorrhizal Fungi (INVAM) (Morgantown, WV, USA), and were then cultured by our laboratory. The inoculated media were culture media with spores, hyphae, and infected root segments. The potassium solubilizing bacteria Bacillus mucilaginosus (effective viable bacteria $\geq 2 \times 10^{10} \mathrm{cfu} \cdot \mathrm{g}^{-1}$ ) and phosphate solubilizing bacteria Bacillus megaterium (effective viable bacteria $\geq 2 \times 10^{10} \mathrm{cfu} \cdot \mathrm{g}^{-1}$ ) were provided by Weiyuan Biotechnology Co., Ltd., (Guangzhou, China).

\subsection{Plant Materials}

On 26 July 2017, fresh 3-year-old bulbs of F. taipaiensis were collected from the Hongchiba cultivation base, Wuxi, Chongqing, China, and then were stored at $4{ }^{\circ} \mathrm{C}$ in the laboratory.

\subsection{Reference Drugs}

Uracil, guanine, uridine, adenine, thymidine, and adenosine standard references (Batch numbers were 100469-200401, 140631-201205, 110887-200202, 886-200001, 101215201401 and 110879-200202, respectively) were obtained from the China National Institutes for Food and Drug Control (NIFDC) (Beijing, China). Cytidine, guanosine, and 2'-deoxyadenosine reference standards (purity $>98 \%$ ) were purchased from Dulai Biotechnology Co., Ltd., (Nanjing, China). Both peimisine and sipeimine reference standards (purity $>$ 98\%) were obtained from Mansit Biotechnology Co., Ltd., (Chengdu, China). Acetonitrile and methanol with chromatographic purity were acquired from Merck Company (Chengdu, China).

\subsection{Cultivation Management and Sample Collection}

The culture medium was a mixture of humus soil and sand with a ratio of 3:1. The culture medium was dried, screened, and sterilized at $121^{\circ} \mathrm{C}$ for $2 \mathrm{~h}$. Cultivation containers $(0.5 \mathrm{~m}($ width $) \times 1 \mathrm{~m}$ (length) $\times 0.3 \mathrm{~m}($ depth $))$ were used in this study. The cultivation containers were disinfected with $10 \% \mathrm{NaClO}$ for $15 \mathrm{~min}$ and then were thoroughly rinsed with purified water. The $F$. taipaiensis bulbs were not disinfected to maintain the original exogenous and endophytic microorganisms. On 27 August 2017, the F. taipaiensis bulbs were planted in a uniform layer of microbial agents and were covered by $5-6 \mathrm{~cm}$ of the surface soil. The plant spacing was $3 \sim 4 \mathrm{~cm}$, and the row spacing was $16 \sim 18 \mathrm{~cm}$. A total of 30 F. taipaiensis bulbs were planted in each container, three containers for each treatment group. A completely randomized design was used in this study, experimental materials in the follow-up study would be collected randomly from the three containers in each treatment. The inoculated groups were: Claroideoglomus claroideum treatment group (Cc, about 1360 C. claroideum spores for each container), Racocetra coralloidea treatment group (Rco, about 1430 R. coralloidea spores for each container), potassium solubilizing bacteria treatment group (Ksb, $35 \mathrm{~g}$ Bacillus mucilaginosus inoculum for each container), phosphorus solubilizing bacteria treatment group (Psb, $35 \mathrm{~g}$ Bacillus megaterium inoculum for each container), a mixed treatment group of $C$. claroideum, $R$. coralloidea, potassium solubilizing bacteria and phosphorus solubilizing bacteria group ( $\mathrm{Mi}$, mixed inoculation of C. claroideum, R. coralloidea, B. mucilaginosus and B. megaterium, the application amount of each microbial 
inoculum was the $1 / 4$ of the former 4 groups) and control group (CK, no microbial agents were used). The plants were grown outdoors, each container was watered according to the real time weather and was supplemented with $1000 \mathrm{~mL}$ Hoagland's nutrient solution [39] once a week. On 29 May 2018, the bulbs, fibrous roots, leaves, and rhizospheric soils of F. taipaiensis at the beginning of blooming stage were harvested: the leaves were used to determine the activity of protective enzymes and the contents of photosynthetic pigments, malondialdehyde, soluble sugar, and soluble protein immediately after harvest; the bulbs were washed and dried at $45^{\circ} \mathrm{C}$ for analysis; the fibrous roots were preserved for mycorrhizal colonization and infection intensity analysis; rhizospheric soil was collected and preserved for soil microbial quantity and soil enzyme activity determination.

\subsection{Analysis of Mycorrhizal Colonization}

The fibrous roots of $F$. taipaiensis from each cultivation container were cut into segments about $1 \mathrm{~cm}$ long and then soaked in FAA fixative solution $(75 \%(V / V)$ ethanol.90 $\mathrm{mL}+$ glacial aceticacid $5 \mathrm{~mL}+40 \%(\mathrm{~V} / \mathrm{V})$ formaldehyde $5 \mathrm{~mL})$. Fifty root segments with uniform thickness of each container were randomly selected and stained according to the method outlined in the literature [40] to calculate the mycorrhizal colonization percentage and mycorrhizal infection intensity. Root segments of $F$. taipaiensis with uniform thickness about $1 \mathrm{~cm}$ long were treated with $10 \% \mathrm{KOH}$ in a $90{ }^{\circ} \mathrm{C}$ water bath for $45 \mathrm{~min}$, and were then acidified with $2 \% \mathrm{HCl}$ for $5 \mathrm{~min}$ after washing with distilled water $3 \sim 5$ times. After acidification, the root segments were stained with $0.05 \%$ trypan blue in a $90{ }^{\circ} \mathrm{C}$ water bath for $30 \mathrm{~min}$, and then were decolorized in glycerol lactate solution (1:1:1) for $24 \mathrm{~h}$. The stained root segments were examined under the microscope to calculate the mycorrhizal colonization percentage and the mycorrhizal infection intensity based on the method of Trouvelot et al. [41]: colonization percentage $=$ (number of infected root segments $/$ total number of examined root segments $) \times 100 \%$; infection intensity $=(95 \cdot \mathrm{n} 5+70 \cdot \mathrm{n} 4+30 \cdot \mathrm{n} 3$ $+5 \cdot n 2+n 1$ )/total number of examined root segments $\times 100 \%$, where $n 5$ is the number of root segments with level 5 infection, $n 4$ is the number of root segments with level 4 infection, etc.

\subsection{Determination of Physiological and Biochemical Indices of Leaves}

Healthy mature leaves of $F$. taipaiensis from the base to the upper and middle parts with uniform size were selected from 5 plants randomly in each treatment, and the contents of the main photosynthetic pigments in the leaves such as chlorophyll $\mathrm{a}$, chlorophyll $\mathrm{b}$ and carotenoid were determined according to the method in the literature via spectrophotometry [42]. The activities of superoxide dismutase (SOD) and peroxidase (POD) were determined by the nitrogen blue tetrazole method and the guaiacol method, respectively, via spectrophotometry, and the activity of catalase (CAT) was determined by the ultraviolet absorption method [42]. The content of malondialdehyde (MDA) and soluble sugar was determined using a thiobarbituric acid method and anthrone method, respectively, via spectrophotometry [42]. The content of soluble protein was determined by the Coomassie brilliant blue method via spectrophotometry [42]. Five biological replicates and three technical replicates were used in the determinations above.

\subsection{Count of Rhizosphere Microorganism}

The microorganisms (bacteria, fungi, and actinomycetes) in the rhizospheric soil of F. taipaiensis were counted by dilution plate counting method (CFU.g ${ }^{-1}$ dry soil) $[43,44]$. The bacteria were cultured on beef extract peptone medium $\left(1 \mathrm{~g} \cdot \mathrm{L}^{-1}\right.$ yeast extract $+5 \mathrm{~g} \cdot \mathrm{L}^{-1}$ tryptone $+5 \mathrm{~g} \cdot \mathrm{L}^{-1}$ beef extract $+5 \mathrm{~g} \cdot \mathrm{L}^{-1}$ sucrose $+0.5 \mathrm{~g} \cdot \mathrm{L}^{-1} \mathrm{MgSO}_{4} \cdot 7 \mathrm{H}_{2} \mathrm{O}+15 \mathrm{~g} \cdot \mathrm{L}^{-1}$ agar, $\mathrm{pH} 7.0)$, the fungi were cultured on Martin medium $\left(2 \mathrm{~g} \cdot \mathrm{L}^{-1}\right.$ yeast extract $+5 \mathrm{~g} \cdot \mathrm{L}^{-1}$ tryptone $+20 \mathrm{~g} \cdot \mathrm{L}^{-1}$ glucose $+1 \mathrm{~g} \cdot \mathrm{L}^{-1} \mathrm{KH}_{2} \mathrm{PO}_{4} \cdot 3 \mathrm{H}_{2} \mathrm{O}+0.5 \mathrm{~g} \cdot \mathrm{L}^{-1} \mathrm{MgSO}_{4} \cdot 7 \mathrm{H}_{2} \mathrm{O}+15 \mathrm{~g} \cdot \mathrm{L}^{-1}$ agar, $\mathrm{pH}$ 6.4), and the actinomycetes were cultured on actinomycetes culture medium (20 g. $\mathrm{L}^{-1}$ soluble starch $+0.5 \mathrm{~g} \cdot \mathrm{L}^{-1} \mathrm{NaCl}+1 \mathrm{~g} \cdot \mathrm{L}^{-1} \mathrm{KNO}_{3}+0.5 \mathrm{~g} \cdot \mathrm{L}^{-1} \mathrm{KH}_{2} \mathrm{PO}_{4} \cdot 3 \mathrm{H}_{2} \mathrm{O}+$ 
$0.5 \mathrm{~g} \cdot \mathrm{L}^{-1} \mathrm{MgSO}_{4} \cdot 7 \mathrm{H}_{2} \mathrm{O}+0.01 \mathrm{~g} \cdot \mathrm{L}^{-1} \mathrm{FeSO}_{4} \cdot 7 \mathrm{H}_{2} \mathrm{O}+15 \mathrm{~g} \cdot \mathrm{L}^{-1}$ agar, $\mathrm{pH}$ 7.6). Five biological replicates and three technical replicates were used in the assays above.

\subsection{Determination of Enzyme Activity in Rhizospheric Soil}

Soil enzyme activity was determined according to a previously described approach $[45,46]$. Briefly, invertase activity was determined by the 3,5-dinitrosalicylic acid colorimetric method, expressed in terms of the glucose content in $1 \mathrm{~g}$ dry soil $24 \mathrm{~h}\left(37^{\circ} \mathrm{C}\right)$ after treatment. Urease activity was determined by the sodium chlorate-sodium phenol colorimetric method, expressed in terms of the amino nitrogen content in $1 \mathrm{~g}$ dry soil $24 \mathrm{~h}\left(37^{\circ} \mathrm{C}\right)$ after treatment. Protease activity was determined by ninhydrin colorimetry, expressed in terms of the amino acid content in $1 \mathrm{~g}$ dry soil $24 \mathrm{~h}\left(50^{\circ} \mathrm{C}\right)$ after treatment. Catalase activity was determined by pyrogallol colorimetry, expressed in terms of the theogallin content in $1 \mathrm{~g}$ dry soil $20 \mathrm{~min}$ $\left(37^{\circ} \mathrm{C}\right)$ after treatment. Phosphatase was determined by the sodium phenylene phosphate colorimetric method, expressed in terms of the phenol content in $1 \mathrm{~g}$ dry soil $24 \mathrm{~h}\left(37^{\circ} \mathrm{C}\right)$ after treatment. Five biological replicates and three technical replicates were used in the assays above.

\subsection{Quality Analysis of Bulb}

To extract total alkaloids, $2 \mathrm{~g}$ of dried F. taipaiensis bulb powder (passed through a no. 3 sieve) from each sample was used. Total alkaloids were extracted by chloroform-methanol (4:1) mixed solution and then were determined by ultraviolet-visible spectrophotometry according to the literature [3]. The nucleosides were determined by the as-reported method via HPLC [47], and peimisine was determined by the method described in the previous literature via HPLC [10]. Five biological replicates and three technical replicates were used in the assays above.

\subsection{Data Analysis}

The data were analyzed by a single factor (one-way) ANOVA and Tukey's test for multiple comparisons via SPSS 22.0 (SPSS, Inc., Chicago, IL, USA) and Excel 2003 ( $\alpha=0.05$ ). $p<0.05$ indicated statistical significance.

\section{Results}

3.1. Effects of Different Microbial Inoculum Treatments on Mycorrhizal Colonization in the Root System of F. taipaiensis

As shown in Figure 1, when the roots of F. taipaiensis in the different microbial inoculum treatment groups were infected with mycorrhizal fungi, mycorrhizal structures such as arbuscular, endophytic hyphae, external hyphae, and vesicle were formed (Figure S1). However, the infection intensity of the treatments was different among groups. In the CK group, the colonization percentage reached $100 \%$, which was consistent with previous research on Paris polyphylla [48]. Compared with the CK group, the mycorrhizal infection intensity of the five different treatment groups significantly increased $(p<0.05)$.

\subsection{Effects of Different Microbial Inoculum Treatments on Photosynthetic Pigment Content of F. taipaiensis Leaves}

The different microbial inoculum treatments had a different effect on the photosynthetic pigment content of 3-year-old F. taipaiensis plants (Table 1). Compared with the CK group, the contents of carotenoid, chlorophyll a, chlorophyll b, and total chlorophyll in each treatment group were significantly higher $(p<0.05)$, thus indicating that inoculation with beneficial microorganisms in the rhizospheric soil could improve the photosynthetic capacity of F. taipaiensis. The highest contents of carotenoid, chlorophyll a, and chlorophyll $\mathrm{b}$ were seen in the Psb treatment group, followed by Rco and Cc treatment groups, and the lowest were in the CK treatment group. 


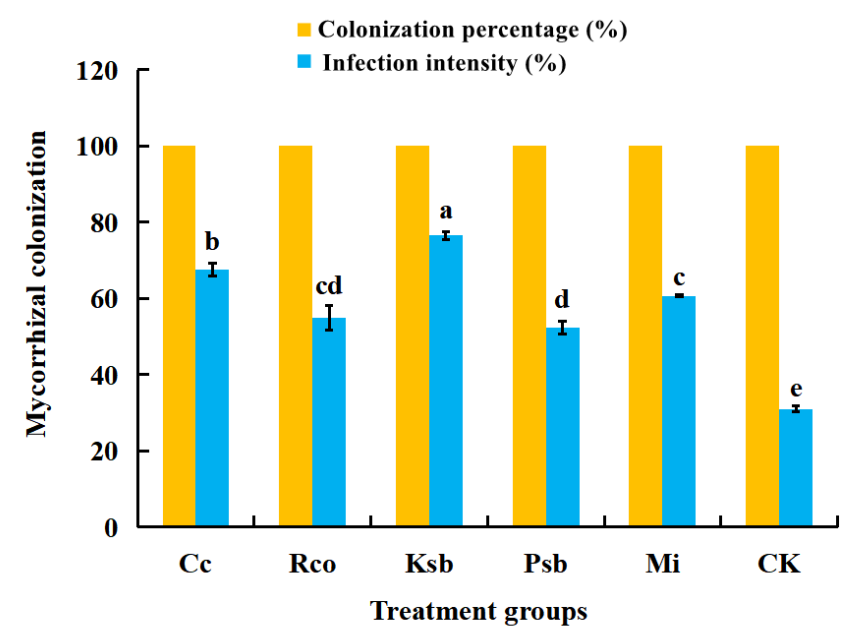

Figure 1. Effects of different microbial inocula on mycorrhizal colonization in the F. taipaiensis root system. The values are means \pm standard deviation of 3 replicates (50 root segments per replicate) randomly selected from each treatment. Different lowercase letters indicate significant differences $(p<0.05)$ in the infection intensity among the six treatments. Cc: Claroideoglomus claroideum treatment group, about 1360 C. claroideum spores for each container; Rco: Racocetra coralloidea treatment group, about 1430 R. coralloidea spores for each container; Ksb: potassium solubilizing bacteria treatment group, $35 \mathrm{~g}$ Bacillus mucilaginosus inoculum for each container; Psb: phosphorus solubilizing bacteria treatment group, $35 \mathrm{~g}$ Bacillus megaterium inoculum for each container; Mi: mixed treatment group with mixed inoculum of C. claroideum, R. coralloidea, B. mucilaginosus, and B. megaterium, the application amount of each microbial inoculum was 1/4 of the former 4 groups; CK: control group, no microbial inocula were used.

Table 1. Effects of different microbial inocula on the photosynthetic pigment content of the F. taipaiensis leaves (fresh weight).

\begin{tabular}{|c|c|c|c|c|}
\hline Group & $\begin{array}{l}\text { Carotenoid } \\
\left(\mathrm{mg} \cdot \mathrm{g}^{-1}\right)\end{array}$ & $\begin{array}{l}\text { Chlorophyll a } \\
\left(\mathrm{mg} \cdot \mathrm{g}^{-1}\right)\end{array}$ & $\begin{array}{l}\text { Chlorophyll b } \\
\left(\mathrm{mg} \cdot \mathrm{g}^{-1}\right)\end{array}$ & $\begin{array}{l}\text { Chlorophyll }(a+b) \\
\left(m g \cdot g^{-1}\right)\end{array}$ \\
\hline CK & $84.08 \pm 0.39 \mathrm{~d}$ & $0.96 \pm 0.01 \mathrm{~d}$ & $0.29 \pm 0.01 \mathrm{~d}$ & $1.25 \pm 0.05 \mathrm{~d}$ \\
\hline $\mathrm{Cc}$ & $134.07 \pm 0.93 b$ & $1.61 \pm 0.02 \mathrm{~b}$ & $0.45 \pm 0.01 b$ & $2.06 \pm 0.03 b$ \\
\hline Rco & $135.76 \pm 0.59 \mathrm{~b}$ & $1.64 \pm 0.01 \mathrm{ab}$ & $0.45 \pm 0.01 \mathrm{~b}$ & $2.09 \pm 0.01 \mathrm{bc}$ \\
\hline $\mathrm{Ksb}$ & $119.92 \pm 2.40 \mathrm{c}$ & $1.44 \pm 0.04 c$ & $0.40 \pm 0.01 c$ & $1.84 \pm 0.02 b c$ \\
\hline Psb & $141.65 \pm 0.56 \mathrm{a}$ & $1.66 \pm 0.01 \mathrm{a}$ & $0.48 \pm 0.01 \mathrm{a}$ & $2.14 \pm 0.01 \mathrm{a}$ \\
\hline $\mathrm{Mi}$ & $119.33 \pm 0.28 c$ & $1.47 \pm 0.01 \mathrm{c}$ & $0.40 \pm 0.01 \mathrm{c}$ & $1.88 \pm 0.01 \mathrm{c}$ \\
\hline
\end{tabular}

The values are means \pm standard deviation of 5 plants randomly selected from each treatment. Different lowercase letters in a column indicate significant differences based on Tukey's test $(p<0.05)$. Cc: Claroideoglomus claroideum treatment group, about 1360 C. claroideum spores for each container; Rco: Racocetra coralloidea treatment group, about 1430 R. coralloidea spores for each container; Ksb: potassium solubilizing bacteria treatment group, $35 \mathrm{~g}$ Bacillus mucilaginosus inoculum for each container; Psb: phosphorus solubilizing bacteria treatment group, $35 \mathrm{~g}$ Bacillus megaterium inoculum for each container; Mi: mixed treatment group with mixed inoculum of $C$. claroideum, R. coralloidea, B. mucilaginosus, and B. megaterium, the application amount of each microbial inoculum was $1 / 4$ of the former 4 groups; CK: control group, no microbial inocula were used.

3.3. Effects of Different Microbial Inoculum Treatments on the Activities of Protective Enzymes in the Leaves of F. taipaiensis

Compared with the CK group, the activities of CAT, POD, and SOD in the leaves of F. taipaiensis increased in different microbial inoculum treatment groups $(p<0.05)$, thus indicating that inoculation of beneficial microorganisms in the rhizospheric soil could enhance the activities of protective enzymes in the leaves of F. taipaiensis (Figure 2). Among these results, the increase in SOD activity of the treatment groups was more obvious than that of CAT, which was consistent with a previous study [49]. Meanwhile, for POD activity, the increase on the Mi group was remarkably higher compared to the other groups, which 
showed that multiple beneficial microorganisms treatment was more effective in improving the POD activity in F. taipaiensis leaves than single microorganism treatment.

3.4. Effects of Different Microbial Inoculum Treatments on Malondialdehyde, Soluble Sugar, and Soluble Protein Content in the Leaves of F. taipaiensis

As shown in Figure 3, different MDA contents were observed in the leaves of F. taipaiensis treated with different beneficial microorganisms. Except for the Ksb group, the MDA content in the other microbial inoculum treatment groups was significantly lower than that in the CK group $(p<0.05)$. On the other hand, the soluble protein content of the microbial inoculum treatment groups was significantly higher than that in the CK group $(p<0.05)$. However, no obvious change $(p>0.05)$ in the soluble sugar contents was observed compared with the CK group.
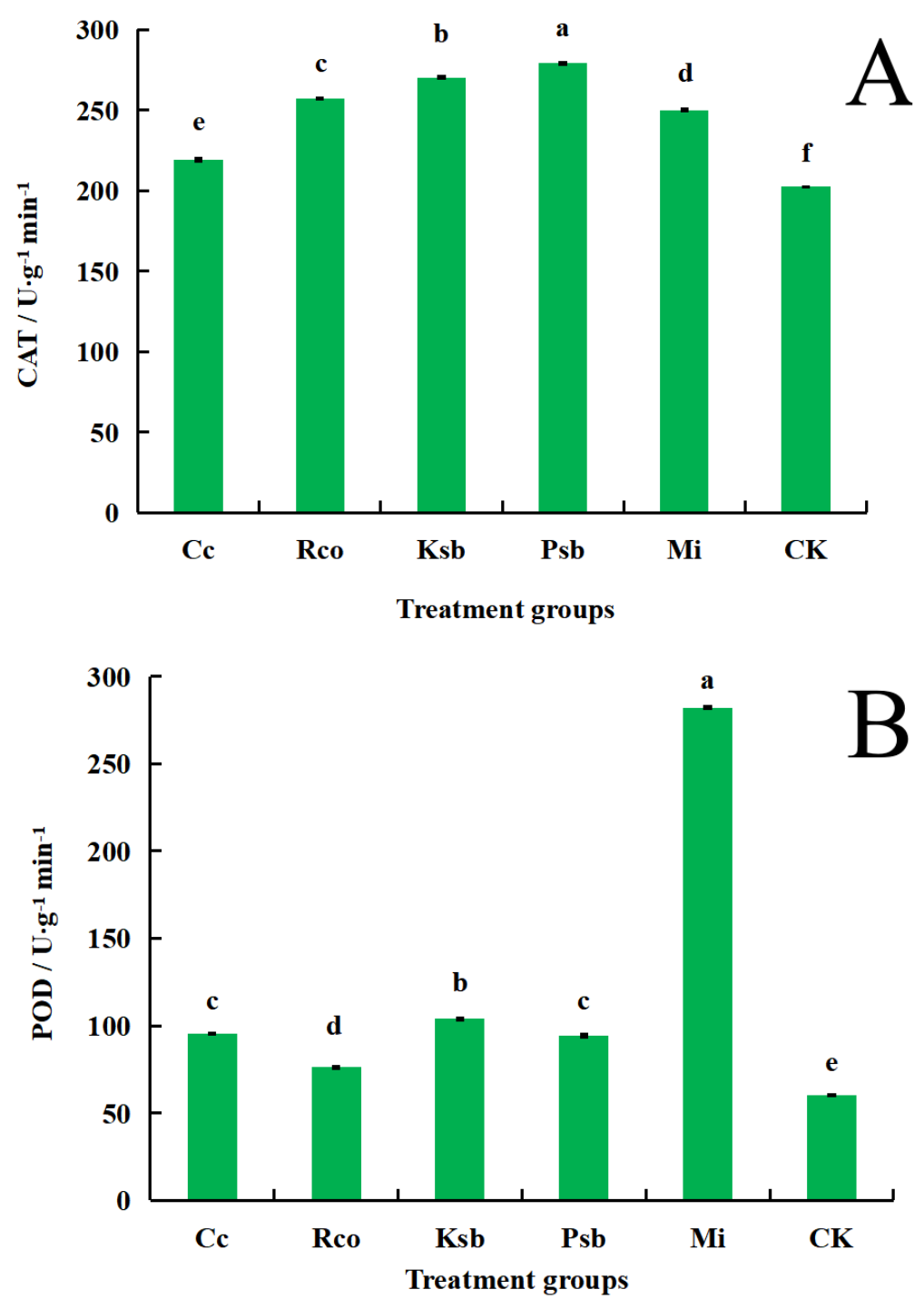

Figure 2. Cont. 


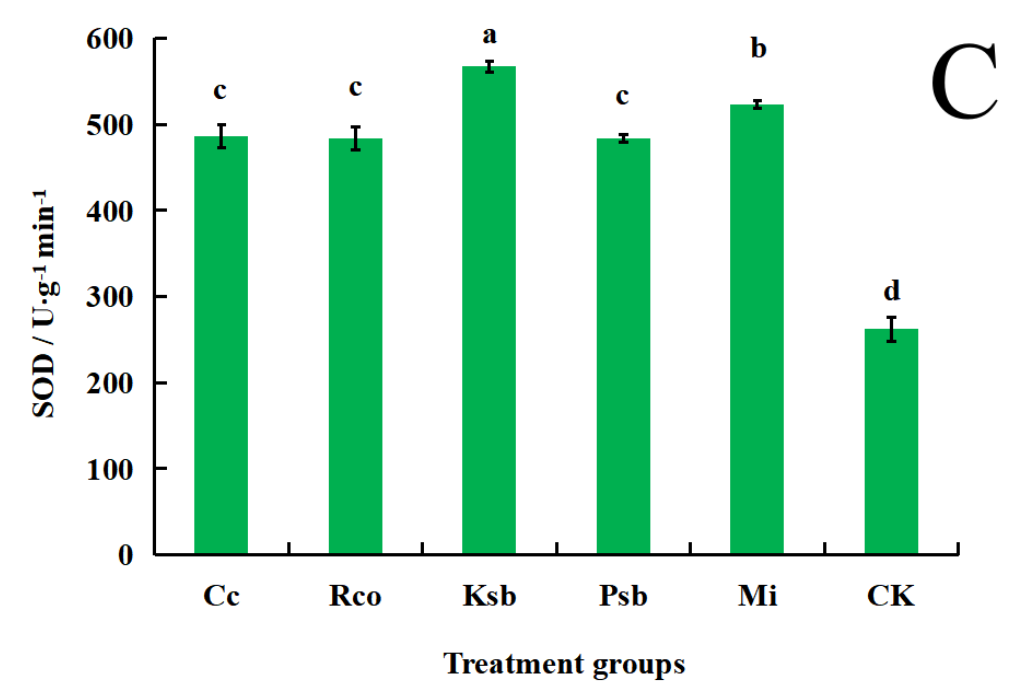

Figure 2. Effects of different microbial inocula on the CAT (catalase), POD (peroxidase), and SOD (superoxide dismutase) enzyme activities of $F$. taipaiensis leaves. The values are means \pm standard deviation of 5 plants randomly selected from each treatment. Different lowercase letters indicate significant differences $(p<0.05)$. (A) CAT contents in the leaves of each treatment group. (B) POD contents in the leaves of each treatment group. (C) SOD contents in the leaves of each treatment group. Cc: Claroideoglomus claroideum treatment group, about 1360 C. claroideum spores for each container; Rco: Racocetra coralloidea treatment group, about 1430 R. coralloidea spores for each container; Ksb: potassium solubilizing bacteria treatment group, $35 \mathrm{~g}$ Bacillus mucilaginosus inoculum for each container; Psb: phosphorus solubilizing bacteria treatment group, $35 \mathrm{~g}$ Bacillus megaterium inoculum for each container; Mi: mixed treatment group with mixed inoculum of C. claroideum, $R$. coralloidea, B. mucilaginosus, and B. megaterium, the application amount of each microbial inoculum was $1 / 4$ of the former 4 groups; CK: control group, no microbial inocula were used.

\subsection{Effects of Different Microbial Inoculum Treatments on the Number of Culturable Bacteria, Fungi, and Actinomycetes in the Rhizospheric Soil of F. taipaiensis}

As shown in Table 2, under the treatments of different microbial inocula, the number of bacteria, fungi, actinomycetes, and total microorganisms significantly increased compared with the CK group $(p<0.05)$. It can be seen that the application of different microbial inocula could effectively increase the number of culturable microorganisms in the soil and significantly promote the number of bacteria and actinomycetes in the soil. In addition, all microbial inoculum treatment groups had a higher bacteria/fungi ratio than the CK group. Moreover, except for the Rco and Psb groups, the microbial inoculum treatment groups also had a higher actinomycetes/fungi ratio than the CK group.

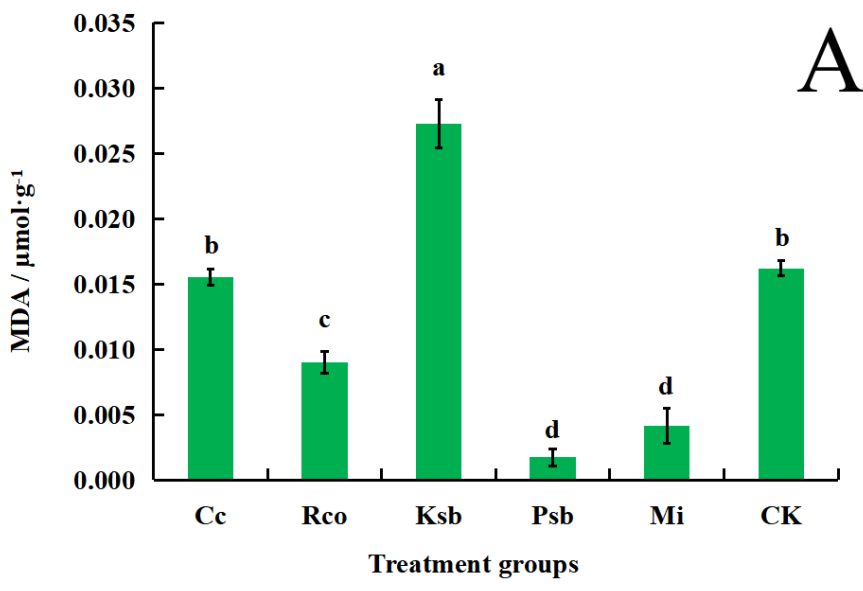

Figure 3. Cont. 

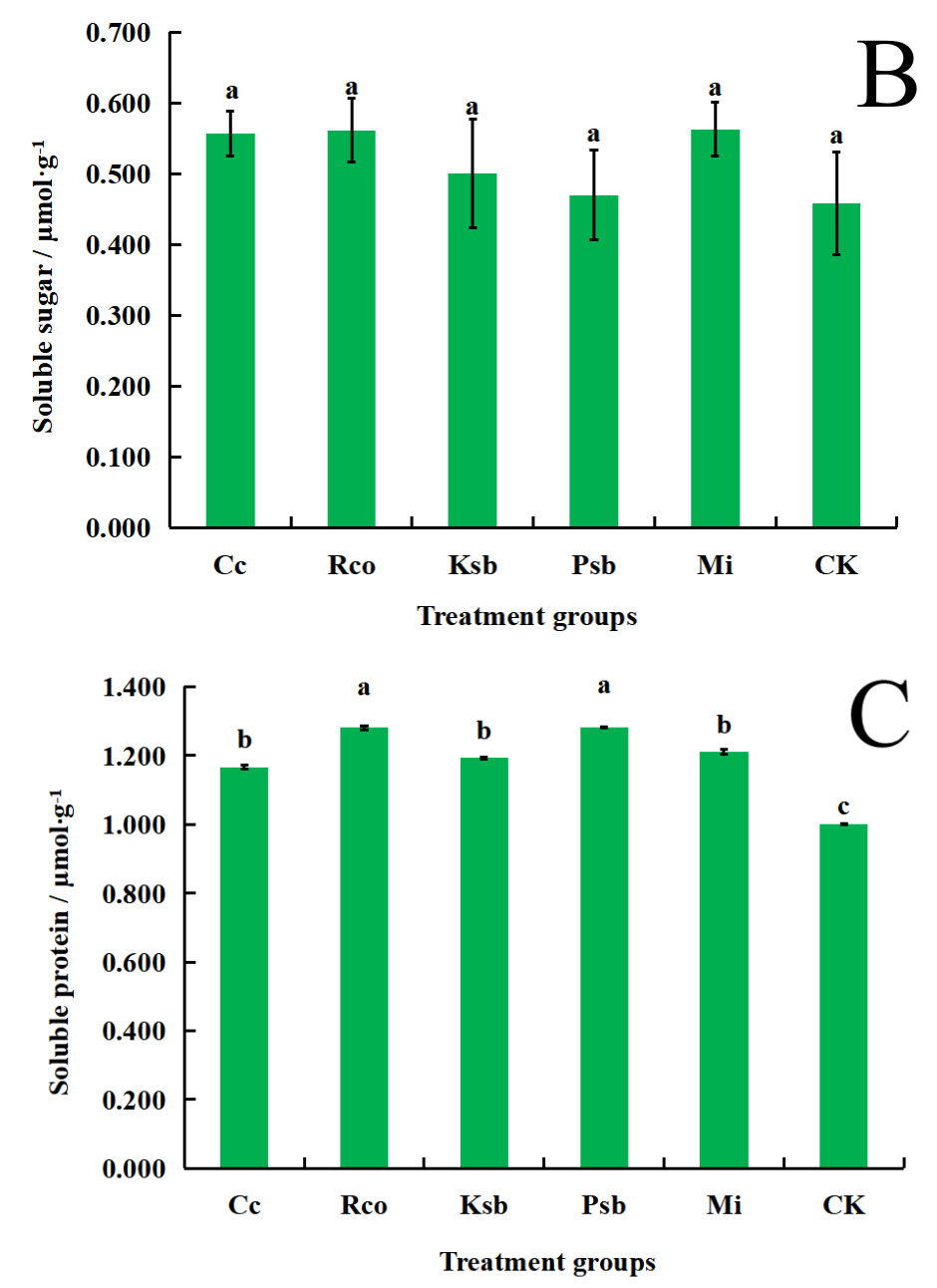

Figure 3. Effect of different microbial inocula on MDA (malondialdehyde), soluble sugar, and soluble protein content of $F$. taipaiensis leaves. Different lowercase letters indicate significant differences $(p<0.05)$ in the infection intensity among the six treatments. The values are means \pm standard deviation of 5 plants randomly selected from each treatment. (A) MDA, (B) soluble sugar, and (C) soluble protein content in the leaves of each treatment group. Cc: Claroideoglomus claroideum treatment group, about 1360 C. claroideum spores for each container; Rco: Racocetra coralloidea treatment group, about 1430 R. coralloidea spores for each container; Ksb: potassium solubilizing bacteria treatment group, $35 \mathrm{~g}$ Bacillus mucilaginosus inoculum for each container; Psb: phosphorus solubilizing bacteria treatment group, $35 \mathrm{~g}$ Bacillus megaterium inoculum for each container; Mi: mixed treatment group with mixed inoculum of C. claroideum, R. coralloidea, B. mucilaginosus, and B. megaterium, the application amount of each microbial inoculum was $1 / 4$ of the former 4 groups; CK: control group, no microbial inocula were used.

3.6. Effects of Different Microbial Inoculum Treatments on Enzyme Activity in Rhizospheric Soil of F. taipaiensis

As the core evaluation index of soil fertility, the activity of soil enzymes is an important indicator reflecting the biological activity of the soil [50]. As shown in Table 3, compared with the CK group, the activities of protease, urease, phosphatase, catalase, and invertase in the rhizospheric soil of 3-year-old F. taipaiensis were significantly increased in microbial inoculum treatment $(p<0.05)$. These data suggested that the beneficial microorganisms accelerated the humification of the rhizospheric soil to a certain extent, thus effectively improving the soil enzyme activity in the rhizosphere of F. taipaiensis. 
Table 2. Comparison of rhizosphere microbial number of F. taipaiensis treated with different microbial inocula.

\begin{tabular}{ccccccc}
\hline Group. & $\begin{array}{c}\text { Bacteria } \\
\mathbf{( l g C F U / g )}\end{array}$ & $\begin{array}{c}\text { Fungi } \\
\mathbf{( 1 g C F U / g )}\end{array}$ & $\begin{array}{c}\text { Actinomycetes } \\
\mathbf{( l g C F U / g )}\end{array}$ & $\begin{array}{c}\text { Total } \\
\text { Microorganisms } \\
\text { (lgCFU/g) }\end{array}$ & Bacteria/Fungi & $\begin{array}{c}\text { Actinomycetes/ } \\
\text { Fungi }\end{array}$ \\
\hline $\mathrm{CK}$ & $5.36 \pm 0.26 \mathrm{c}$ & $3.55 \pm 0.05 \mathrm{~d}$ & $4.40 \pm 0.04 \mathrm{c}$ & $5.42 \pm 0.23 \mathrm{~b}$ & $80.10 \pm 4.78 \mathrm{e}$ & $7.31 \pm 0.30 \mathrm{c}$ \\
$\mathrm{Cc}$ & $5.88 \pm 0.22 \mathrm{~b}$ & $3.72 \pm 0.05 \mathrm{ab}$ & $4.69 \pm 0.08 \mathrm{a}$ & $5.92 \pm 0.20 \mathrm{a}$ & $164.94 \pm 7.69 \mathrm{c}$ & $9.42 \pm 0.39 \mathrm{a}$ \\
$\mathrm{Rco}$ & $5.92 \pm 0.11 \mathrm{ab}$ & $3.67 \pm 0.04 \mathrm{c}$ & $4.50 \pm 0.03 \mathrm{~b}$ & $5.94 \pm 0.09 \mathrm{a}$ & $186.36 \pm 5.38 \mathrm{~b}$ & $6.77 \pm 0.91 \mathrm{c}$ \\
$\mathrm{Ksb}$ & $6.03 \pm 0.09 \mathrm{a}$ & $3.65 \pm 0.01 \mathrm{c}$ & $4.54 \pm 0.03 \mathrm{~b}$ & $6.05 \pm 0.09 \mathrm{a}$ & $255.30 \pm 8.86 \mathrm{a}$ & $8.12 \pm 0.61 \mathrm{~b}$ \\
$\mathrm{Psb}$ & $5.84 \pm 0.05 \mathrm{~b}$ & $3.73 \pm 0.05 \mathrm{a}$ & $4.52 \pm 0.03 \mathrm{~b}$ & $5.87 \pm 0.05 \mathrm{a}$ & $145.05 \pm 6.17 \mathrm{~d}$ & $6.48 \pm 0.45 \mathrm{c}$ \\
$\mathrm{Mi}$ & $5.93 \pm 0.14 \mathrm{ab}$ & $3.83 \pm 0.08 \mathrm{a}$ & $4.74 \pm 0.10 \mathrm{a}$ & $5.97 \pm 0.05 \mathrm{a}$ & $135.48 \pm 4.36 \mathrm{~d}$ & $8.29 \pm 0.81 \mathrm{ab}$ \\
\hline
\end{tabular}

The values are means \pm standard deviation of 5 soil samples randomly selected from each treatment. Different lowercase letters in a column indicate significant differences based on Tukey's test $(p<0.05)$. Cc: Claroideoglomus claroideum treatment group, about 1360 C. claroideum spores for each container; Rco: Racocetra coralloidea treatment group, about 1430 R. coralloidea spores for each container; Ksb: potassium solubilizing bacteria treatment group, $35 \mathrm{~g}$ Bacillus mucilaginosus inoculum for each container; Psb: phosphorus solubilizing bacteria treatment group, $35 \mathrm{~g}$ Bacillus megaterium inoculum for each container; Mi: mixed treatment group with mixed inoculum of $C$. claroideum, $R$. coralloidea, B. mucilaginosus, and B. megaterium, the application amount of each microbial inoculum was $1 / 4$ of the former 4 groups; CK: control group, no microbial inocula were used.

Table 3. Effects of different microbial inocula on rhizospheric soil enzyme activity of F. taipaiensis.

\begin{tabular}{|c|c|c|c|c|c|c|c|}
\hline Group & $\begin{array}{c}\text { Protease } \\
\left(\mathrm{mg} \cdot \mathbf{k g}^{-1}\right)\end{array}$ & $\begin{array}{c}\text { Urease } \\
\left(\mathrm{g} \cdot \mathrm{kg}^{-1}\right)\end{array}$ & $\begin{array}{c}\text { Acid } \\
\text { Phosphatase } \\
\left(\mathrm{g} \cdot \mathrm{kg}^{-1}\right)\end{array}$ & $\begin{array}{c}\text { Neutral } \\
\text { Phosphatase } \\
\left(\mathrm{g} \cdot \mathrm{kg}^{-1}\right)\end{array}$ & $\begin{array}{c}\text { Alkaline } \\
\text { Phosphatase } \\
\left(\mathrm{g} \cdot \mathrm{kg}^{-1}\right)\end{array}$ & $\begin{array}{l}\text { Catalase } \\
\left(\mathrm{g} \cdot \mathrm{kg}^{-1}\right)\end{array}$ & $\begin{array}{c}\text { Invertase } \\
\left(\mathrm{g} \cdot \mathrm{kg}^{-1}\right)\end{array}$ \\
\hline CK & $29.286 \pm 0.104 \mathrm{~d}$ & $15.719 \pm 0.077 \mathrm{~d}$ & $0.255 \pm 0.016 \mathrm{~d}$ & $0.162 \pm 0.012 c$ & $0.037 \pm 0.013 \mathrm{~d}$ & $0.162 \pm 0.004 \mathrm{f}$ & $12.604 \pm 0.062 \mathrm{e}$ \\
\hline $\mathrm{Cc}_{\mathrm{C}}$ & $64.035 \pm 0.051 b$ & $16.617 \pm 0.086 \mathrm{~d}$ & $0.812 \pm 0.069 b$ & $0.264 \pm 0.008 \mathrm{a}$ & $0.086 \pm 0.019 b$ & $0.324 \pm 0.011 \mathrm{~d}$ & $12.955 \pm 0.001 \mathrm{e}$ \\
\hline Rco & $54.266 \pm 0.028 c$ & $33.081 \pm 0.034 b$ & $0.541 \pm 0.018 c$ & $0.237 \pm 0.030 \mathrm{a}$ & $0.118 \pm 0.009 \mathrm{a}$ & $0.384 \pm 0.002 b$ & $25.074 \pm 0.087 \mathrm{c}$ \\
\hline $\mathrm{Ksb}$ & $29.686 \pm 0.154 \mathrm{~d}$ & $28.924 \pm 0.001 \mathrm{c}$ & $0.871 \pm 0.036 b$ & $0.190 \pm 0.014 \mathrm{bc}$ & $0.087 \pm 0.002 \mathrm{bc}$ & $0.426 \pm 0.025 \mathrm{a}$ & $32.223 \pm 0.074 b$ \\
\hline Psb & $78.242 \pm 0.019 a$ & $41.365 \pm 0.027 \mathrm{a}$ & $0.778 \pm 0.056 b$ & $0.208 \pm 0.035 \mathrm{ab}$ & $0.089 \pm 0.007 \mathrm{bc}$ & $0.339 \pm 0.064 c$ & $36.624 \pm 0.039 a$ \\
\hline $\mathrm{Mi}$ & $72.726 \pm 0.047 \mathrm{a}$ & $33.766 \pm 0.004 b$ & $2.442 \pm 0.071 \mathrm{a}$ & $0.171 \pm 0.023 b c$ & $0.039 \pm 0.004 \mathrm{~cd}$ & $0.206 \pm 0.024 \mathrm{e}$ & $14.467 \pm 0.003 \mathrm{~d}$ \\
\hline
\end{tabular}

The values are means \pm standard deviation of 5 soil samples randomly selected from each treatment. Different lowercase letters in a column indicate significant differences based on Tukey's test $(p<0.05)$. Cc: Claroideoglomus claroideum treatment group, about 1360 C. claroideum spores for each container; Rco: Racocetra coralloidea treatment group, about 1430 R. coralloidea spores for each container; Ksb: potassium solubilizing bacteria treatment group, $35 \mathrm{~g}$ Bacillus mucilaginosus inoculum for each container; Psb: phosphorus solubilizing bacteria treatment group, $35 \mathrm{~g}$ Bacillus megaterium inoculum for each container; Mi: mixed treatment group with mixed inoculum of $C$. claroideum, R. coralloidea, B. mucilaginosus, and B. megaterium, the application amount of each microbial inoculum was 1/4 of the former 4 groups; CK: control group, no microbial inocula were used.

\subsection{Effects of Different Microbial Inoculum Treatments on Nucleosides in the Bulb of F. taipaiensis}

The concentration of nucleosides in the bulbs of 3-year-old F. taipaiensis was affected to different degrees by applying different microbial inocula (Table 4). There were some differences in the contents of the nine nucleotides in F. taipaiensis bulbs under different treatments. Compared with that of the CK group, the content of cytidine, guanine, uridine, guanosine, thymidine, adenosine, 2 '-deoxyadenosine, and the total content of nucleosides in bulbs under microbial inoculum treatments increased, while the contents of uracil and adenine decreased (all $p<0.05$ ). The order of the total nucleoside content from high to low was $\mathrm{Mi}>\mathrm{Ksb}>\mathrm{Cc}>\mathrm{Psb}>\mathrm{Rco}>\mathrm{CK}$, in which the highest was Mi at $1449.98 \mu \mathrm{g} \cdot \mathrm{g}^{-1}$, and the lowest was $\mathrm{CK}$ at $959.65 \mu \mathrm{g} \cdot \mathrm{g}^{-1}$.

\subsection{Effects of Different Microbial Inoculum Treatments on Alkaloids in the Bulb of F. taipaiensis}

As seen in Table 5 , the content of total alkaloids and peimisine was significantly increased in each microbial inoculum treatment group compared to the CK group $(p<0.05)$. The order of total alkaloid content was Psb $>\mathrm{Ksb}>\mathrm{Cc}>\mathrm{Mi}>\mathrm{Rco}>\mathrm{Ck}$; the highest total alkaloid content was $1.10 \mathrm{mg} \cdot \mathrm{g}^{-1}$ in the Psb treatment, the lowest was $0.57 \mathrm{mg} \cdot \mathrm{g}^{-1}$ in the CK treatment. The order of peimisine content was Rco $>\mathrm{Cc}>\mathrm{Psb}>\mathrm{Ksb}>\mathrm{Mi}>\mathrm{CK}$; the highest peimisine content was $0.40 \mathrm{mg} \cdot \mathrm{g}^{-1}$ in the Rco treatment, and the lowest was $0.26 \mathrm{mg} \cdot \mathrm{g}^{-1}$ for CK. Both of Rco and Cc had high peimisine contents, but the difference between them was not statistically significant $(p>0.05)$. Therefore, applying different beneficial microorganisms in the rhizosphere can effectively increase the content of alkaloids in the bulb of $F$. taipaiensis and promote the content of peimisine in the bulb. 
Table 4. The nucleoside content of F. taipaiensis bulbs treated by different microbial inocula $\left(\mu \mathrm{g} \cdot \mathrm{g}^{-1}\right.$, fresh weight).

\begin{tabular}{|c|c|c|c|c|c|c|c|c|c|c|}
\hline Group & Uracil & Cytidine & Guanine & Uridine & Adenine & Guanosine & Thymidine & Adenosine & $\begin{array}{c}2^{\prime}- \\
\text { Deoxyadenosine }\end{array}$ & Total \\
\hline CK & $38.385 \pm 0.640 a$ & $24.730 \pm 1.318 b$ & $23.745 \pm 1.633 \mathrm{e}$ & $223.737 \pm 1.178 \mathrm{f}$ & $51.757 \pm 0.826 \mathrm{a}$ & $232.013 \pm 1.648 \mathrm{f}$ & $28.042 \pm 0.998 \mathrm{f}$ & $310.870 \pm 0.340 \mathrm{e}$ & $26.373 \pm 1.435 \mathrm{e}$ & $951.932 \pm 2.678 \mathrm{f}$ \\
\hline $\mathrm{Cc}$ & $16.355 \pm 0.710 c$ & $48.862 \pm 0.233 a$ & $30.296 \pm 0.093 \mathrm{~d}$ & $339.488 \pm 0.371 \mathrm{c}$ & $28.650 \pm 0.455 \mathrm{~d}$ & $321.895 \pm 1.367 \mathrm{~b}$ & $98.703 \pm 0.453 a$ & $377.707 \pm 0.272 \mathrm{c}$ & $106.974 \pm 2.469 a$ & $1352.576 \pm 0.423 c$ \\
\hline Rco & $13.114 \pm 0.316 \mathrm{~d}$ & $27.358 \pm 1.425 b$ & $60.227 \pm 1.633 b$ & $271.344 \pm 0.490 \mathrm{e}$ & $36.767 \pm 0.074 b$ & $260.075 \pm 1.633 \mathrm{e}$ & $51.107 \pm 0.540 \mathrm{e}$ & $340.540 \pm 0.306 \mathrm{~d}$ & $57.505 \pm 4.764 \mathrm{~d}$ & $982.581 \pm 1.799 \mathrm{e}$ \\
\hline Ksb & $17.628 \pm 0.268 c$ & $25.236 \pm 0.825 b$ & $87.911 \pm 2.267 \mathrm{a}$ & $343.810 \pm 0.182 b$ & $24.047 \pm 0.222 \mathrm{e}$ & $316.040 \pm 2.397 \mathrm{c}$ & $84.102 \pm 0.647 b$ & $399.131 \pm 1.059 \mathrm{~b}$ & $91.504 \pm 0.325 b$ & $1370.242 \pm 0.185 \mathrm{~b}$ \\
\hline Psb & $16.584 \pm 0.682 c$ & $25.124 \pm 0.816 b$ & $46.803 \pm 0.801 \mathrm{c}$ & $279.541 \pm 0.468 \mathrm{~d}$ & $33.324 \pm 0.946 c$ & $266.124 \pm 1.676 \mathrm{~d}$ & $58.658 \pm 1.788 d$ & $346.949 \pm 0.301 \mathrm{~d}$ & $59.356 \pm 4.563 \mathrm{~d}$ & $1110.430 \pm 8.132 \mathrm{~d}$ \\
\hline Mi & $23.143 \pm 0.230 \mathrm{~b}$ & $52.328 \pm 1.633 a$ & $24.280 \pm 0.486 \mathrm{e}$ & $362.572 \pm 1.152 \mathrm{a}$ & $51.382 \pm 0.099 a$ & $364.171 \pm 1.135 \mathrm{a}$ & $76.347 \pm 1.420 c$ & $417.247 \pm 0.977 \mathrm{a}$ & $78.514 \pm 0.944 c$ & $1426.841 \pm 6.054 \mathrm{a}$ \\
\hline
\end{tabular}

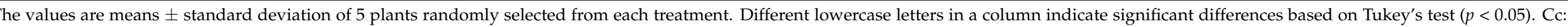

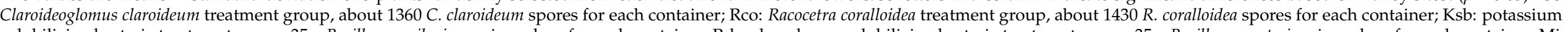

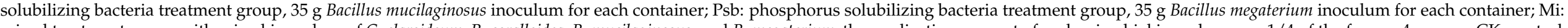

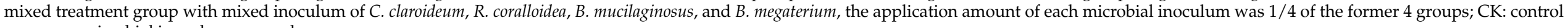
group, no microbial inocula were used. 
Table 5. The alkaloid content of the F. taipaiensis bulbs treated with different microbial inocula $\left(\mathrm{mg} \cdot \mathrm{g}^{-1}\right)$.

\begin{tabular}{ccc}
\hline Group & Peimisine & Total Alkaloids \\
\hline CK & $0.26 \pm 0.01 \mathrm{c}$ & $0.57 \pm 0.01 \mathrm{e}$ \\
Cc & $0.39 \pm 0.01 \mathrm{a}$ & $1.04 \pm 0.01 \mathrm{~b}$ \\
Rco & $0.40 \pm 0.01 \mathrm{a}$ & $0.84 \pm 0.01 \mathrm{~d}$ \\
Ksb & $0.33 \pm 0.01 \mathrm{~b}$ & $1.08 \pm 0.01 \mathrm{ab}$ \\
Psb & $0.33 \pm 0.01 \mathrm{~b}$ & $1.10 \pm 0.02 \mathrm{a}$ \\
Mi & $0.32 \pm 0.01 \mathrm{~b}$ & $0.90 \pm 0.03 \mathrm{c}$ \\
\hline
\end{tabular}

The values are means \pm standard deviation of 5 plants randomly selected from each treatment. Different lowercase letters in a column indicate significant differences based on Tukey's test $(p<0.05)$. Cc: Claroideoglomus claroideum treatment group, about 1360 C. claroideum spores for each container; Rco: Racocetra coralloidea treatment group, about 1430 R. coralloidea spores for each container; Ksb: potassium solubilizing bacteria treatment group, $35 \mathrm{~g}$ Bacillus mucilaginosus inoculum for each container; Psb: phosphorus solubilizing bacteria treatment group, $35 \mathrm{~g}$ Bacillus megaterium inoculum for each container; Mi: mixed treatment group with mixed inoculum of $C$. claroideum, R. coralloidea, B. mucilaginosus, and B. megaterium, the application amount of each microbial inoculum was $1 / 4$ of the former 4 groups; CK: control group, no microbial inocula were used.

\section{Discussion}

This study revealed a symbiotic relationship between 3-year-old F. taipaiensis and the beneficial microorganisms in the rhizospheric soil. Under simulated field cultivation conditions, the inoculation increased the mycorrhizal infection intensity of $F$. taipaiensis. No significant difference was found in the colonization percentage of the root mycorrhiza ( $p>0.05)$ among the microbial inoculum treatment groups, while the root of the CK group was also colonized by mycorrhizal fungi, which might be due to a certain amount of fungi that the bulbs carried from their original cultivation soil [51]. Moreover, the mycorrhizal fungi infection intensities of the treatment groups were significantly higher compared to the CK group $(p<0.05)$, indicating that the inoculations with AM fungi, potassium solubilizing and phosphorus solubilizing bacteria could enhance the infection intensity of mycorrhizal fungi in F. taipaiensis. The infection intensity of Psb was relatively low among the treatment groups, which might be due to the absorption of more phosphorus in F. taipaiensis. A previous study reported that the growth of mycorrhizal fungi is inhibited when phosphorus exceeds certain levels [52].

The biochemical indices of chlorophyll, soluble sugar, soluble protein contents, and enzyme activities in the leaves of medicinal plants can reflect their photosynthetic efficiency, health, and antioxidant capacity to a certain extent [42]. In this paper, we found that beneficial microorganisms in rhizospheric soil promoted the accumulation of photosynthetic pigments such as chlorophyll and improved carotenoid. The leaves of F. taipaiensis in the Psb group had the highest photosynthetic pigments content in this study. The reason may be consistent with a previous study: the phosphate solubilizing bacteria Bacillus megaterium can not only solubilize phosphate fixed in the soil to provide plants fertilizer, but can also stimulate the growth of plant by the secretion of cytokinin [53]. Soluble protein is an essential osmoregulation substance and nutrient in plants that can alleviate ion imbalances and physiological droughts caused by salt and drought stress [54], which is involved in the stress resistance of plants. In this study, the soluble protein content in the leaves of the treatment groups were significantly higher than that in CK group, which is consistent with the result of a previous study [49,55]. Furthermore, other studies revealed that the increase in the leaf soluble protein content of plants can be caused by the increase of nitrate reductase enzyme activity, higher nitrogen fixation, and growth hormone production through AM fungi and microbial fertilizer application [56,57]. CAT, POD, and SOD in the plants can reduce membrane lipid peroxidation, maintaining and protecting the stability of the cell membrane structure and function [55]. In this study, the activities of CAT, POD, and SOD in the treatment groups were all significantly higher than that in CK, especially in the Mi group, which had the highest POD activity among the groups. This result is consistent with a previous study [58] that reported multiple applications of AM fungi, potassium solubilizing bacteria and phosphate solubilizing bacteria had more distinguished effects on 
promoting antioxidant peroxidase activity in plants than single applications of them. The content of MDA could reflect the degree of cell damage, such as cellular lipid peroxidation and chlorophyll decomposition [59]. However, the MDA content of the leaves in the Ksb group were higher than in other groups, including the CK group: in the other groups, MDA levels were lower compared to the CK group. A previous study reported that the decrease of MDA content was not synchronized with increases of CAT, POD, and SOD content after the application of the potassium solubilizing bacteria Bacillus mucilaginosus. The MDA content in the leaves of the plant first briefly decreased and then increased when the potassium solubilizing bacteria application exceeded a certain level, while the contents of CAT, POD, and SOD kept an upward trend at the same time [60]. Therefore, the suitable amount of solubilizing bacteria required to assure the increase of CAT, POD, and SOD contents and a decrease of the MDA content simultaneously in F. taipaiensis is a subject worth exploring. In general, all these data suggest that beneficial microorganisms can promote the contents of photosynthetic pigment, osmoregulation substances, and the activity of superoxide dismutase in F. taipaiensis.

Changes of the soil microbial community structure have an important role in soil health, which is one of the main factors leading to continuous cropping obstacles of medicinal plants $[12,13]$. Some studies showed that the number of bacteria in the cultivated soil declined while the number of fungi increased with the cultivation year, and the soil microbial population type converted from a bacterial type to fungal type [61]. Among the bacteria that decline are nitrogen-fixing bacteria, potassium solubilizing bacteria, and phosphate solubilizing bacteria, which may impoverish the soil [61]. Actinomycetes can produce antibiotics, protecting plants from disease; their decrease may increase the risk of plant disease [62]. On the other hand, fungi that accumulated in the soil during the cultivation contained many plant pathogens. In this study, we found that the different microbial inoculum treatments increased the number of total microorganisms, bacteria/fungi ratio, and actinomycetes/fungi ratio, which was similar to previous results [9] where the application of microbial fertilizer affected the number of soil microorganisms in the rhizosphere of 2-year-old F. taipaiensis. The higher bacteria/fungi and actinomycetes/fungi ratio could correspond to a lower risk of pathogens in the soil, on the contrary, the low bacteria/fungi and actinomycetes/fungi ratio indicates more potential hazards [62]. Meanwhile, Ou et al. [63] found that the number of bacteria and actinomycetes in the rhizosphere of Paris polyphylla var. yunnanensis significantly increased, and the number of fungi decreased after applying AM fungal fertilizer. Nonetheless, in this study, the number of fungi in the rhizosphere of microbial inoculum treatment groups was significantly higher than that of the CK group. There were different results on the effect of applying microbial fertilizer on the number of microorganisms in the rhizospheric soil of medicinal plants, which might be due to differences in their fertilization types, plant varieties, and soil conditions [9,63]. In general, the results showed that the application of beneficial microorganisms could reduce the risk of disease or infection for F. taipaiensis.

Soil enzyme activity is considered an important indicator of soil fertility and soil nutrient transformability. Soil enzymes participate in all biochemical processes in soil and have an important role in the soil ecosystem. For example, protease and urease participate in soil nitrogen transformation; catalase can reduce toxicity to plants by decomposing hydrogen peroxide; invertase can decompose macromolecular organic matter into glucose and fructose, thus improving the soil nutritional status [64]. In this study, we found that the activities of protease, urease, catalase, and invertase in the rhizospheric soil of 3-year-old F. taipaiensis increased after applying microbial inoculum, which could be related to the quantity and community structure change in the F. taipaiensis rhizosphere caused by the beneficial microorganisms. The activities of acid phosphatase, neutral phosphatase, and alkaline phosphatase in the rhizospheric soil of most microbial inoculum treatment groups in this study were significantly higher than that of the CK group. However, the neutral phosphatase, and alkaline phosphatase activities of the Mi group showed no significant difference compared to the CK group. Phosphatase could speed up the mineralization of 
organic phosphorus in the soil to increase available phosphorus content [64], but its activity is easily affected by environmental factors [65]. The different phosphatase activities in the different microbial inoculum treatment groups might be related to environmental factors such as $\mathrm{pH}$, soil organic phosphorus content, soil moisture content, temperature, and the interaction of microorganisms.

Over recent years, AM fungi, solubilizing bacteria, and other beneficial microorganisms in the rhizospheric soil have been reported to regulate secondary metabolite production and increase the content of the active component in medicinal plants $[48,66]$. At present, steroidal alkaloids and nucleosides are widely used as effective components in the quality evaluation of F. taipaiensis [1,3]. In this study, the content and composition of the chemical components in $F$. taipaiensis were significantly affected by beneficial soil microorganisms. Total nucleoside, total alkaloid, and peimisine content of each microbial inoculum treatment group were significantly higher than those of the CK group, indicating that the beneficial microorganisms had a beneficial effect on the medicinal quality of $F$. taipaiensis and regulated its secondary metabolites. In F. taipaiensis, nucleoside was considered an active ingredient that could promote the development of intestinal tenue, regulate the metabolism of lipids, and participate in various physiological processes of the human body by controlling purine and pyrimidine receptors [67-69]. Meanwhile, in plants, nucleoside content is an important indicator that reflects the status and speed of growth [68]. Among the microbial inoculum treatment groups, the Mi group had the lowest alkaloid and peimisine contents and the highest total nucleosides, which reflected the balance and antagonism between the growth and the accumulation of the secondary metabolite. In this study, the promoting effect of the contents of photosynthetic pigment, osmoregulation substances and active ingredients in 3-year-old F. taipaiensis was the comprehensive result of multiple factors, which may be related to the amount of microbial inoculum [70], the species of microorganisms, and interactions between the different microorganisms [9]. Of course, the intrinsic mechanisms need to be further explored. In our future study, we plan to design a different gradient of microbial bacteria to find the best and the most economical amount of fertilizer.

\section{Conclusions}

In summary, the inoculation of beneficial microorganisms in rhizospheric soil can improve mycorrhizal fungi colonization in the root system of $F$. taipaiensis, increasing the contents of chlorophyll and other photosynthetic pigments in the leaves of F. taipaiensis, enhancing the accumulation of soluble sugar, soluble protein, and other osmoregulation substances, reducing the content of MDA, and protective enzymes such as SOD, POD, and CAT in the leaves of the plants. Moreover, the activity of soil enzymes (protease, urease, phosphatase, catalase, and invertase) was promoted, the number of culturable microorganisms (bacteria, fungi, and actinomycetes) was increased, as was the content of alkaloids and nucleosides in the bulb of $F$. taipaiensis. Beneficial microorganism inoculation has great scientific significance and potential application value that can be used to further develop the beneficial microbial resources in the rhizosphere soil of F. taipaiensis.

Supplementary Materials: The following are available online at https: / www.mdpi.com/article / 10.3390/horticulturae7110500/s1, Figure S1: Mycorrhizal structure in the F. taipaiensis root system. (A) arbuscular, (B) endophytic hyphae, (C) external hyphae, (D) vesicle and (E) spore.

Author Contributions: Conceptualization, N.Z. and Y.Z.; methodology, M.M. (Mingguo Ma); software, M.M. (Maojun Mu); validation, N.Z., Y.Z. and M.M. (Maojun Mu).; formal analysis, N.Z.; investigation, M.M. (Maojun Mu) and Y.Z.; resources, M.M. (Mingguo Ma) and M.Y.; data curation, M.Y.; writing — original draft preparation, N.Z. and M.M. (Mingguo Ma); writing-review and editing, Y.Z.; visualization, Y.Z.; supervision, M.M. (Maojun Mu); project administration, M.M. (Mingguo Ma); funding acquisition, N.Z., Y.Z., M.M. (Mingguo Ma) and M.Y. All authors have read and agreed to the published version of the manuscript. 
Funding: This research was funded by the Chongqing basic and frontier research project (CSTC2013 jcyjA10120), basic project of Chongqing Municipal Education Commission (KJQN202101231), key project of Chongqing Municipal Education Commission (KJZD-K202101201), Chongqing Natural Science Foundation Project (cstc2021jcyj-msxmX0115) and "Chunhui plan" project of the Ministry of Education (Z2015150).

Institutional Review Board Statement: Not applicable.

Informed Consent Statement: Not applicable.

Data Availability Statement: Not applicable.

Acknowledgments: We wish to thank Hua Zhang (Chongqing Three Gorges University), Dongqin Guo (Chongqing Three Gorges University) for critical reading and expertise on the analysis.

Conflicts of Interest: The authors declare no conflict of interest.

\section{References}

1. Shen, L.; Zhou, N.; Fu, S.-Z.; Yi, D.-Y.; Jia, H.; Chen, H.-Y.; Wu, Y.-M. Pharmacognostical study on cultivated Fritillaria taipaiensis. J. Chin. Med. Mater. 2014, 37, 45-49. [CrossRef]

2. Huang, Y.B.; Liu, H.M.; Fang, C.X.; Yu, Y.; Chen, H.Z.; Zhang, S.Y.; Li, S.M.; Hui, A.O. Comparative study on the pharmacodynamic differences of the Anti-tussive and Anti-inflammatory effects of the alkaloids from different varieties of Fritillariae cirrhosae Bulbs. Tradit. Chin. Drug Res. Clin. Pharmacol. 2018, 29, 19-22. [CrossRef]

3. Zhou, N.; Guo, D.Q.; Shen, L.; Chen, Q.Y.; Tan, Y. Comparative contents of four alkaloids in bulbs of Fritillaria taipaiensis and Fritillaria unibracteata. Food Sci. 2014, 35, 133-136. [CrossRef]

4. Chinese Pharmacopoeia Commission. Chuanbeimu. In Pharmacopoeia of the People's Republic of China, 1st ed.; Zhao, Y.Y., Fan, Z.X., Huang, K.., Li, Z., Gao, Y.M., Eds.; China Medical Science Press: Beijing, China, 2015; p. 36.

5. Wang, L.Z. Quality Study on Fritillarias Cirrhosae Bulbus. Master's Thesis, Peking Union Medical College, Beijing, China, 2013.

6. Fu, S.Z.; Yuan, D.M.; Ou, Y.J.; Li, J.D.; Lu, Q.F. Discussion on the development history and countermeasures of Fritillaria Taipaiensis P.Y.Li in chongqing. Lishizhen Med. Mater. Med. Res. 2014, 25, 476-477. [CrossRef]

7. Zhou, N.; Ding, B.; Guo, D.Q.; Zhang, D.Q.; Li, S.S. Comparative study on the microstructure of stem and leaf between wild and cultivated Fritillaria Taipaiensis P. Y. Li. J. Chin. Med. Mater. 2015, 38, 77-80. [CrossRef]

8. Fu, S.Z. Ecological types and protection countermeasures of wild Fritillaria Taipaiensis P. Y. Li in three gorges area of Yangtze River. Lishizhen Med. Mater. Med. Res. 2012, 23, 2018-2019. [CrossRef]

9. Dong, T.W. The Effect of Combined Application of Nitrogen Phosphorus Fertilizer and Microbial Fertilizer on Growth and Quality of Two-Year-old Fritillaria Taipaiensis P. Y. Li. Master's Thesis, Northwest A\&F University, Xianyang, China, 2018.

10. Peng, R.; Ma, P.; Mo, R.; Sun, N. Analysis of the bioactive components from different growth stages of Fritillaria taipaiensis P. Y. Li. Acta Pharm. Sin. B 2013, 3, 167-173. [CrossRef]

11. Mu, M.J.; Zhou, X.Q.; Guo, D.Q.; Wang, Q.; Yang, M.; Zhang, H.; Zhou, N. Effect of growth years to the soil enzyme activities and heavy metal residue of Fritillaria taipaiensis P. Y. Li. Environ. Chem. 2019, 38, 1966-1972. [CrossRef]

12. Xiao, Y.H.; Li, Q.; Liu, Z.X.; Li, Y.J.; Li, G.; Long, H. Advances in studies on rhizospheric microorganism of medicinal plants. Chin. Tradit. Herb. Drugs 2013, 44, 497-504. [CrossRef]

13. Qiao, Q.M.; Cheng, M.G.; Wang, X.M. The potential of rhizosphere microbes in relieveing continuous cropping obstacle of medicinal plants. Chin. J. Soil Sci. 2009, 40, 957-961. [CrossRef]

14. Geng, S.J.; Wang, B.; Liu, K.; Shang, H.Y.; Quan, J.J.; Lu, X.P.; Shen, Q.R. Effect of specific microbial fertilizer on the rhizosphere microbial flora of different continuous cropping obstacles soil. Jiangsu J. Agric. Sci. 2012, 28, 758-764. [CrossRef]

15. Schübler, A.; Schwarzott, D.; Walker, C. A new fungal phylum, the Glomeromycota: Phylogenny and evolution. Mycol. Res. 2001, 105, 1413-1421. [CrossRef]

16. Tanaka, Y.; Yano, K. Nitrogen delivery to maize via mycorrhizal hyphae depends on the form of N supplied plant. Cell Environ. 2005, 28, 1247-1254. [CrossRef]

17. Etesami, H.; Jeong, B.R.; Glick, B.R. Contribution of Arbuscular Mycorrhizal Fungi, Phosphate-Solubilizing Bacteria, and Silicon to P Uptake by Plant. Front. Plant Sci. 2021, 12, 699618. [CrossRef]

18. Mortimer, P.E.; Pérez-Fernández, M.; Valentine, A.J. Arbuscular mycorrhiza maintains nodule function during external $\mathrm{NH}_{4}{ }^{+}$ supply in Phaseolus vulgaris (L.). Mycorrhiza 2012, 22, 237-245. [CrossRef]

19. Wang, S.; Chen, A.; Xie, K.; Yang, X.; Luo, Z.; Chen, J.; Zeng, D.; Ren, Y.; Yang, C.; Wang, L.; et al. Functional analysis of the OsNPF4.5 nitrate transporter reveals a conserved mycorrhizal pathway of nitrogen acquisition in plants. Proc. Natl. Acad. Sci. USA 2020, 117, 16649-16659. [CrossRef]

20. Wang, Y.; Xing, D.; Song, L.L.; Han, S.Y.; Chen, T.S. Effects of arbuscular mycorrhizal fungi on nutrient exchange in mulberry plant in rocky desertification areas. Chin. J. Tropical. Crop. 2020, 41, 7-14. [CrossRef] 
21. Balestrini, R.; Brunetti, C.; Cammareri, M.; Caretto, S.; Cavallaro, V.; Cominelli, E.; De Palma, M.; Docimo, T.; Giovinazzo, G.; Grandillo, S.; et al. Strategies to Modulate Specialized Metabolism in Mediterranean Crops: From Molecular Aspects to Field. Int. J. Mol. Sci. 2021, 22, 2887. [CrossRef]

22. Yu, M.; Xie, W.; Zhang, X.; Zhang, S.; Wang, Y.; Hao, Z.; Chen, B. Arbuscular Mycorrhizal Fungi Can Compensate for the Loss of Indigenous Microbial Communities to Support the Growth of Liquorice (Glycyrrhiza uralensis Fisch.). Plants 2019, 9, 7. [CrossRef] [PubMed]

23. Santander, C.; Aroca, R.; Ruiz-Lozano, J.M.; Olave, J.; Cartes, P.; Borie, F.; Cornejo, P. Arbuscular mycorrhiza effects on plant performance under osmotic stress. Mycorrhiza 2017, 27, 639-657. [CrossRef]

24. Sanmartín, N.; Pastor, V.; Pastor-Fernández, J.; Flors, V.; Pozo, M.J.; Sánchez-Bel, P. Role and mechanisms of callose priming in mycorrhiza-induced resistance. J. Exp. Bot. 2020, 71, 2769-2781. [CrossRef] [PubMed]

25. Zhao, X.; Wang, B.W.; Yan, X.F. Effect of arbuscular mycorrhiza on camptothecin content in Camptotheca acuminata seedlings. Acta. Ecologica. Sinica 2006, 4, 1057-1062. [CrossRef]

26. Guo, Q.S.; Cheng, L.T.; Liu, Z.Y. Study on influence of arbuscular mycorrhizal fungi Pinellia ternata yield and chemical composition. China J. Chin. Mater. Med. 2010, 3, 333-338. [CrossRef]

27. Huang, J.-H.; Tan, J.-F.; Jie, H.-K.; Zeng, R.-S. Effects of inoculating arbuscular mycorrhizal fungi on Artemisia annua growth and its officinal components. J. Appl. Ecol. 2011, 22, 1443-1449. [CrossRef]

28. Saini, I.; Aggarwal, A.; Kaushik, P. Inoculation with Mycorrhizal Fungi and Other Microbes to Improve the Morpho-Physiological and Floral Traits of Gazania rigens (L.) Gaertn. Agriculture 2019, 9, 51. [CrossRef]

29. Vosnjak, M.; Likar, M.; Osterc, G. The Effect of Mycorrhizal Inoculum and Phosphorus Treatment on Growth and Flowering of Ajania (Ajania pacifica (Nakai) Bremer et Humphries). Plant Hortic. 2021, 7, 178. [CrossRef]

30. Mongkolthanaruk, W. Classification of Bacillus Beneficial Substances Related to Plants, Humans and Animals. J. Microbiol. Biotechnol. 2012, 22, 1597-1604. [CrossRef]

31. Kloepper, J.W.; Ryu, C.-M.; Zhang, S. Induced Systemic Resistance and Promotion of Plant Growth by Bacillus spp. Phytopathology 2004, 94, 1259-1266. [CrossRef]

32. Liu, S.; Tang, W.; Yang, F.; Meng, J.; Chen, W.; Li, X. Influence of biochar application on potassium-solubilizing Bacillus mucilaginosus as potential biofertilizer. Prep. Biochem. Biotechnol. 2017, 47, 32-37. [CrossRef] [PubMed]

33. Zhang, A.M.; Li, N.K.; Zhao, G.Y.; Zhang, S.F. Research progress on the phosphate-solubilizing and potassium-solubilizing microorganism. J. Hebei Univ. 2015, 35, 442-448. [CrossRef]

34. Gundala, P.B.; Chinthala, P.; Sreenavasulu, B. A new facultative alkaliphilic potassium solubilizing Bacillus sp. SVUNM9 isolated from mica cores of Nellore District, Andhra Pradesh, India: Research and reviews. J. Microbiol. Biotechn. 2013, 2, 1-7.

35. Bhatt, K.; Maheshwari, D.K. Zinc solubilizing bacteria (Bacillus megaterium) with multifarious plant growth promoting activities alleviates growth in Capsicum annuum L. 3 Biotech 2020, 10, 36. [CrossRef]

36. Kang, S.-M.; Radhakrishnan, R.; You, Y.-H.; Joo, G.-J.; Lee, I.-J.; Lee, K.-E.; Kim, J.-H. Phosphate Solubilizing Bacillus megaterium mj1212 Regulates Endogenous Plant Carbohydrates and Amino Acids Contents to Promote Mustard Plant Growth. Indian J. Microbiol. 2014, 54, 427-433. [CrossRef] [PubMed]

37. Jiang, F.; Zhang, L.; Zhou, J.; George, T.S.; Feng, G. Arbuscular mycorrhizal fungi enhance mineralisation of organic phosphorus by carrying bacteria along their extraradical hyphae. New Phytol. 2020, 230, 304-315. [CrossRef]

38. Feitosa de Souza, T.A.; Rodriguez-Echeverría, S.; Alves de Andrade, L.; Freitas, H. Arbuscular mycorrhizal fungi in Mimosa tenuiflora (Willd.) Poir from Brazilian semi-arid. Braz. J. Microbiol. 2016, 47, 359-366. [CrossRef] [PubMed]

39. Van Delden, S.H.; Nazarideljou, M.J.; Marcelis, L.F.M. Nutrient solutions for Arabidopsis thaliana: A study on nutrient solution composition in hydroponics systems. Plant Methods 2020, 16, 72. [CrossRef]

40. Philips, J.M.; Hayman, D.S. Improved procedures for clearing and attaining parasitic and vesicular mycorrhizal fungi for rapid assessment of infection. Trans. Br. Mycol. Soc. 1970, 55, 158-162. [CrossRef]

41. Trouvelot, A.; Kough, J.L.; Gianinazzi, P.V. Mesure du taux de mycorhization VA d'un système radiculaire. Recherche de méthodes d'estimation ayant une signification fonctionnelle. In Physiological and Genetical Aspects of Mycorrhizae, 1st ed.; Gianinazzi-Pearson, V., Gianinazzi, S., Eds.; INRA Publications: Paris, France, 1986; pp. 154-156.

42. Zhang, Z.L.; Qu, W.J.; Li, X.F. Plant Physiology Experiment Instruction, 1st ed.; Higher Education Press: Beijing, China, 2009.

43. Wright, S.F.; Upadhyaya, A. A survey of soils for aggregate stability and glomalin, a glyco protein produced by hyphae of arbuscular mycorrhizal fungi. Plant Soil 1998, 198, 97-107. [CrossRef]

44. Lin, X.G. Principles and Methods of Soil Microbial Research, 1st ed.; Higher Education Press: Beijing, China, 2010.

45. Yan, J.; Han, X.Z.; Wang, S.Q.; Li, X.H.; Zhu, W.W. Effects of different nitrogen forms on microbial quantity and enzymes activities in soybean field. J. Plant. Nutr. Fertil. 2010, 16, 341-347.

46. Guan, S.Y. Soil Enzyme and Its Research Method, 1st ed.; Agricultural Press: Beijing, China, 1986.

47. You, J.; Zhang, D.Q.; Pan, X.J.; Zhang, H.; Zhou, N.; Yu, J.J. Simultaneous determination of nine nucleosides contents using high performance liquid chromatography in Fritillaria taipaiensis P. Y. Li and Fritillaria unibracteata Hsiao et K. C. Hsia. Food Ferment. Ind. 2016, 42, 174-179. [CrossRef]

48. Zhou, N.; Zhang, D.-Q.; Sun, Q.; Jiang, B.; Huang, Z.-C. Effects of fungal elicitors on the secondary metabolite steroidal saponin in Paris polyphylla var. yunnanensis. Acta Pharm. Sin. 2012, 47, 1237-1242. [CrossRef] 
49. Wei, Z.-X.; Guo, D.-Q.; Li, H.-F.; Ding, B.; Zhang, J.; Zhou, N.; Yu, J. Photosynthetic parameters and physiological indexes of Paris polyphylla var. yunnanensis influenced by arbuscular mycorrhizal fungi. China J. Chin. Mater. Med. 2015, 40, 3945-3952. [CrossRef]

50. Wang, W.-L.; Du, J.-B.; Xu, F.-L.; Zhang, X.-H. Effect of fertilization levels on soil microorganism amount and soil enzyme activities. China J. Chin. Mater. Med. 2013, 38, 3851-3856. [CrossRef]

51. Mu, M.-J.; Zhang, D.-G.; Zhang, H.; Yang, M.; Guo, D.-Q.; Zhou, N. Correlation between rhizospheric microorganisms distribution and alkaloid content of Fritillaria taipaiensis. China J. Chin. Mater. Med. 2019, 44, 2231-2235. [CrossRef]

52. Li, W.; Sun, L.Y.; Zhang, C.P.; Xu, M.; Guo, Z.X. Distribution characteristic of arbuscular mycorrhizal fungi in the rhizosphere of endangered Lilium tsingtauense plants. J. Northeast Agric. Univ. 2016, 47, 30-37. [CrossRef]

53. Ortíz-Castro, R.; Valencia-Cantero, E.; López-Bucio, J. Plant growth promotion by Bacillus megaterium involves cytokinin signaling. Plant Signal. Behav. 2008, 3, 263-265. [CrossRef] [PubMed]

54. Muchate, N.S.; Nikalje, G.; Rajurkar, N.S.; Suprasanna, P.; Nikam, T.D. Plant Salt Stress: Adaptive Responses, Tolerance Mechanism and Bioengineering for Salt Tolerance. Bot. Rev. 2016, 82, 371-406. [CrossRef]

55. Kamali, S.; Mehraban, A. Effects of Nitroxin and arbuscular mycorrhizal fungi on the agro-physiological traits and grain yield of sorghum (Sorghum bicolor L.) under drought stress conditions. PLoS ONE 2020, 15, e0243824. [CrossRef]

56. Soltani Kazemi, J.; Aboutalebian, M.A.; Hamzei, J.; Meskarbashee, M. Mycorrhiza and seed priming effect to improve the balance of sodium and potassium and some changes in sodium and potassium and some changes in antioxidants in the leaves of maize (Zea mays L.) under soil salinity. J. Agr. 2018, 17, 18-27. [CrossRef]

57. Nosheen, A.; Bano, A.; Yasmin, H.; Keyani, R.; Habib, R.; Shah, S.T.A.; Rabia, N. Protein quantity and quality of saf-flower seed improved by NP fertilizer and rhizobacteria (Azospirillum and Azotobacter spp.). Front. Plant Sci. 2016, 7, 1-12. [CrossRef] [PubMed]

58. Azmat, A.; Yasmin, H.; Hassan, M.N.; Nosheen, A.; Naz, R.; Sajjad, M.; Ilyas, N.; Akhtar, M.N. Co-application of bio-fertilizer and salicylic acid improves growth, photosynthetic pigments and stress tolerance in wheat under drought stress. PeerJ 2020, 8, e9960. [CrossRef]

59. Abdel-Salam, E.; Alatar, A.; El-Sheikh, M.A. Inoculation with arbuscular mycorrhizal fungi alleviates harmful effects of drought stress on damask rose. Saudi J. Biol. Sci. 2018, 25, 1772-1780. [CrossRef] [PubMed]

60. Wu, J.L.; Luo, X.G.; Li, B.Q.; Li, Z.F.; Yang, S.; Zhong, X.M.; Wu, H.L. Isolation of Bacillus mucilaginosus and its influence on cotton seed germination in the desert sand. Agric. Res. Arid. Area. 2015, 33, 77-82. [CrossRef]

61. Haynes, K.M.; Preston, M.; McLaughlin, J.W.; Webster, K.; Basiliko, N. Dissimilar bacterial and fungal decomposer communities across rich to poor fen peatlands exhibit functional redundancy. Can. J. Soil Sci. 2015, 95, 219-230. [CrossRef]

62. Gu, W.C.; Zhang, J.; Zhou, N.; Pan, X.J.; Ding, B.; Qi, J.S.; Yang, M. Effect of different arbuscular mycorrhizal fungi combinations and inoculation periods on rhizosphere soil physicochemical properties and microbial quantity of Paris polyphylla var. yunnanensis seedlings. Chin. J. Exp. Tradit. Med. Form. 2020, 26, 116-130. [CrossRef]

63. Ou, H.; Guo, D.-Q.; Lin, J.-J.; Yan, Z.-Y.; Teng, Z.; Wang, G.-Z.; Zhou, N. Effects of Different AM Fungi on Quantity and Enzyme Activity of Rhizosphere Soil Microorganism of Paris polyphylla var. yunnanensis. J. Chin. Med. Mater. 2016, 39, 948-955.

64. Liao, H.B.; Li, Y.X.; Shao, J.J.; Fang, F.; Guo, W.D.; Chen, W.R. Impacts of continuous cropping on Fritillaria thunbergii Miq. growth and rhizosphere soil properties. Chin. J. Ecol. 2011, 30, 2203-2208. [CrossRef]

65. Yokoyama, D.; Imai, N.; Kitayama, K. Effects of nitrogen and phosphorus fertilization on the activities of four different classes of fine-root and soil phosphatases in Bornean tropical rain forests. Plant Soil 2017, 416, 463-476. [CrossRef]

66. Fu, X.F.; Zhang, G.P.; Zhang, X.W.; Ren, J.H. Effects of PSB and AMF on growth, microorganisms and soil enzyme activities in the rhizosphere of Taxus chinensis var.mairei Seedlings. Acta Bot. Boreal. Occident. Sin. 2016, 36, 353-360. [CrossRef]

67. Jacobson, K.A.; Jarvis, M.F.; Williams, M. Purine and Pyrimidine (P2) Receptors as Drug Targets. J. Med. Chem. 2002, 45, 4057-4093. [CrossRef] [PubMed]

68. Ralevic, V.; Burnstock, G. Receptors for purines and pyrimidines. Pharmacol. Rev. 1998, 50, 413-492. [CrossRef] [PubMed]

69. Carver, J.; Walker, W.A. The role of nucleotides in human nutrition. J. Nutr. Biochem. 1995, 6, 58-72. [CrossRef]

70. Chen, B.Y.; Ma, H.H.; Yang, T.; Cheng, Z.M.; Niu, X.X.; Ma, X.W. Effect of different microbial fertilizer dosage on the components of Fritillaria pallidiflora Schvek. Xinjiang Agric. Sci. 2017, 54, 871-877. [CrossRef] 